\title{
CLINICAL AND EPIDEMIOLOGICAL PROFILE OF CHILDREN AND ADOLESCENTS SUBMITTED TO THE HEMATOPOIETIC CELL TRANSPLANTATION
}

\author{
PERFIL CLÍNICO E EPIDEMIOLÓGICO DE CRIANÇAS E ADOLESCENTES \\ SUBMETIDOS AO TRANSPLANTE DE CÉLULAS-TRONCO HEMATOPOÉTICAS
}

\author{
Wanessa da Silva Peres BEZERRA ${ }^{1}$; Marcos Antonio FERREIRA JÚNIOR²; \\ Isabelle Campos de AZEVEDO ${ }^{3}$; Mayk Penze CARDOSO ${ }^{4}$; \\ Andreia Insabralde de Queiroz CARDOSO ${ }^{5}$; Oleci Pereira FROTA ${ }^{6}$; \\ Maria Lúcia IVO ${ }^{7}$; Vanessa Giavarotti Taboza FLORES ${ }^{8}$; \\ Elenilda de Andrade Pereira GONÇALVES ${ }^{9}$
}

1. Nurse. Master Student of the Infectious Diseases Program of the School of Medicine, Federal University of Mato Grosso do Sul, Mato Grosso, MS, Brazil; 2. Nurse. Doctorate in Nursing, Adjunct Professor, Federal University of Mato Grosso do Sul, Mato Grosso, MS, Brazil; 3. Nurse. Doctorate in Nursing Student, Federal University of the Rio Grande do Norte and Bone Marrow Transplantation of the Rio Grande Hospital, Natal, RN, Brazil, isabellebr2511@gmail.com; 4. Nurse. Master Student Federal University of Mato Grosso do Sul, Campo Grande, MS, Brazil; 5. Nurse. Master in Nursing, Professor, Federal University of Mato Grosso do Sul, Campo Grande, MS, Brazil; 6. Nurse. Doctorate in Nursing, Adjunct Professor, Federal University of Mato Grosso do Sul, Campo Grande, MS, Brazil; 7. Nurse. PhD in Nursing, Federal University of Mato Grosso do Sul, Campo Grande, MS, Brazil; 8. Nurse. Maria Aparecida Pedrossian University Hospital, Federal University of Mato Grosso do Sul, Campo Grande, MS, Brazil; 9. Nurse. Master Student Federal University of Mato Grosso do Sul, Campo Grande, MS, Brazil.

\begin{abstract}
The Hematopoietic stem cell transplantation (HSCT) is used in children as a definitive treatment for various oncological, immune deficiencies, hemoglobinopathy, and malignancies diseases that involve the hematological system, congenital metabolism disorders, among others. To characterize the clinical and epidemiological profile of children and adolescents submitted to HSCT at a referral service in the state of Rio Grande do Norte. This is a quantitative, retrospective, observational, descriptive and analytical quantitative approach approaching the medical records of children and adolescents submitted to HSCT in a referral hospital service for this type of transplantation in the state of Rio Grande do Sul North (RN). The final sample consisted of 35 records patients aged between 2 and 18 years old who underwent HSCT from February 2008 to December 2015 and who presented the data necessary for the study. The records analyzed showed a little majority of male patients $(51.42 \%)$ and $60.00 \%$ of these men were students and $71.42 \%$ lived in the state of the Rio Grande do Norte. According to the clinical characteristics, $34.3 \%$ of the patients had Acute Lymphoblastic Leukemia and $25.71 \%$ had Acute Myeloid Leukemia as the main diagnosis. Gastrointestinal toxicities were the most frequent $(97.1 \%)$ and all patients received antineoplastic/chemotherapeutic and antiemetic treatment. The allogeneic HSCT was the most frequently performed (57.14\%) and the most used source of Hematopoietic progenitor cells (HPC) was the peripheral blood (54.29\%) and 5.71\% of these patients developed the Graft versus Host Disease (GVHD), of which one was affected by acute GVHD and another by chronic GVHD. Septsis was the most frequent cause of death (60\%). The profile of the clinical variables presented by the children and adolescents of this study shows that the most prevalent diagnosis was ALL, the most frequent toxicities were gastrointestinal, cardiac, respiratory and hematological, the most common HSCT was allogeneic peripheral blood and the greatest cause of mortality was sepsis. These data are similar to studies conducted in North America, Europe and Asia.
\end{abstract}

KEYWORDS: Hematopoietic Stem Cell Transplantation. Bone Marrow Transplantation. Child. Adolescent. Epidemiology.

\section{INTRODUCTION}

Hematopoietic stem cell transplantation (HSCT) is used in children as a definitive treatment for different oncological, immune deficiencies, hemoglobinopathies, and diseases malignancies that involve the hematological system, congenital metabolism disorders, among others. HSCT consists of a treatment option for some of these diseases or even the only option for others that probably have not responded to other therapeutic modalities, with an increase in survival after transplantation, contributing to its use (YEŞILIPEK, 2014).

Although these diseases are indicated for HSCT, there are still some factors that need to be considered such as the underlying disease, the 
clinical conditions of the patient, the existence of a compatible donor, adequate infrastructure for performing the procedure, specialized multiprofessional and trained team, after using other treatment possibilities. Also, the family, psychological and socioeconomic conditions should be considered for continuity of home care after hospital discharge (BRASIL, 2008).

HSCT is a procedure in which hematopoietic stem cells (HTCs) are intravenously infused to restore normal functional bone marrow (BM). To obtain favorable conditions of multiplication for these stem cells and also to cause immunosuppression, in the stage before the transplant, the conditioning is performed, being a stage with high doses of chemotherapy are administered. HSCT is indicated when BM is affected or when hematopoietic toxicity is a limiting factor for the aggressive treatment of the disease (GLUCKMAN, 2012; NORKIN; WINGARD, 2017).

The HSCT is classified according to the donor in autogenic when the patient's cells are collected and cryopreserved for subsequent infusion; syngeneic when collected from homozygous twin; and the allogeneic for which the source of the cells will be a compatible donor that may or may not be related (AZEVEDO et al., 2017a; DANBY; PROTHEROE; ROBERTS, 2017).

Due to advances in supportive care, HSCT is currently a therapeutic modality with significant degrees of success against some diseases that would probably be lethal or would not have definitive cure, such as Sickle Cell Anemia and Aplastic Anemia (FIGUEIREDO; KERBAUY; LOURENÇO, 2011; NASH; GADI, 2011; YEŞILIPEK, 2014). For some patients, treatment with HSCT shows a significant improvement in overall survival (AZEVEDO et al., 2017b; KLUSMANN et al., 2012).

Although HSCT is considered a viable treatment option, it still has some significant limitations (BOUCHER et al., 2015). Its disadvantages are the acute complications resulting from the conditioning period that occurs within the first 100 days after its completion, which may affect several organs and systems and be more severe in the period of medullary aplasia, lasting around 15 to 28 days (BRASIL, 2008). Also, late effects of the transplantation process such as endocrine, metabolic, renal, ophthalmologic and neurocognitive diseases, sequels such as cardiomyopathies, liver dysfunction or cirrhosis, need for hormone replacement, acute or chronic graft versus host disease (GVHD) skeletal and cardiac disorders are also reported. However, solid tumors are considered rare (KLUSMANN et al., 2012; LEVY et al., 2012).

In a retrospective study with 40 children carried out in Uruguay, the most common diagnoses among hematologic malignancies, there were ALL $(\mathrm{n}=15)$ and AML $(\mathrm{n}=13)$. These data are similar to those found in this study. All children were also submitted to HSCT (DUFORT et al., 2016). There are few studies on hematopoietic stem cell transplantation in the Brazilian pediatric population. Thus, it is a procedure that still requires research in the area, which highlights the importance of knowing the clinical and epidemiological profile of children and adolescents submitted to this procedure.

Thus, this study aimed to characterize the clinical and epidemiological profile of children and adolescents submitted to HSCT in a referral service in the state of Rio Grande do Norte, located in the northeast region of Brazil.

\section{MATERIAL AND METHODS}

This is an epidemiological, quantitative, retrospective, observational, descriptive and analytical study. The medical records of children and adolescents submitted to HSCT were analyzed in a reference hospital service for this type of procedure in the state of Rio Grande do Norte.

Data were collected between March and September of 2016 by secondary data. The sources were all medical records of patients aged between two and 18 years old who performed the HSCT in the service from February 2008 until December of 2015, characterizing the cohort follow-up time. For the purposes of this study, the subject with up to 12 years old will be considered as a child, and adolescents will be those between 12 and 18 , according to the Statute of the Child and Adolescent (BRASIL, 1990). Also, HSCT is considered as the outcome for this study.

The study population was composed of all the patients who performed the HSCT in the service studied. The sample was a census type, considering all the existing population, in a total of 35 medical records of children and adolescents attended during the period, with medical indication for performing the HSCT, regardless of the modality of transplantation performed, that met the inclusion and established criteria. The records of patients aged between zero and 18 years old, of both genders, who underwent autologous and allogeneic transplant procedures were included. Two medical records that did not present information capable of providing the 
data necessary for the study due to incompleteness were excluded.

The data collection in the medical records occurred through the completion of a structured instrument, specifically designed for this study, which addressed sociodemographic and clinical variables. The collection of data was performed with the Medical Archive and Statistics Service through prior schedules. The sociodemographic variables were date and place of birth, place of residence, age, gender, race, educational level, family and per capita income, marital status, type of residence, housing characterization, and occupation. Regarding the clinical variables, the following were considered: current situation with the HSCT service, time between the date of diagnosis and the HSCT, time of follow-up by the transplant service, diagnosis that indicated HSCT, main diagnostic tests, type of HSCT performed, presence of toxicities, established treatments, presence of acute or chronic GVHD, causes of death, and transplant survival.

After collected, the data were entered in a Microsoft Excel ${ }^{\circledR} 2010$ spreadsheet, tabulated and organized into tables with absolute and relative frequencies by gender, age, race, marital status, education level, place of residence, diagnoses, toxicities, treatments used, HSCT types, Hematopoietic progenitor cells types (HPC), allogeneic transplant donor, GVHD, causes of death and total.

The protocol of this research was approved by the Research Ethics Committee of the Federal University of Rio Grande do Norte (UFRN) on July 1,2015 , under the opinion of number $1,132,720$, CAAE number 46202715.7.0000.5537, according to the precepts established in Resolution 466/12 of the National Health Council. It was also requested a Letter of Consent and a Term of Concession for the institution where the research was carried out and obeyed the fundamental principles of bioethics.

\section{RESULTS AND DISCUSSION}

There were 18 male of the 35 patients included in the study $(51.42 \%)$, aged between two and 18 years old and with a mean age of 10.91 years old. Among the medical records, $77.16 \%$ did not present information about their race, $60.00 \%$ were students and 71.42 resided in the RN (Table 1).

Table 1. Sociodemographic characteristics of children and adolescents submitted to HSCT in the state of Rio Grande do Norte between 2008 and 2015. Natal/RN, 2017 (n=35).

\begin{tabular}{|c|c|c|}
\hline Variables & $\mathbf{n}$ & $\%$ \\
\hline \multicolumn{3}{|l|}{ Gender } \\
\hline Male & 18 & 51.42 \\
\hline Female & 17 & 48.58 \\
\hline \multicolumn{3}{|l|}{ Age group } \\
\hline 02 to 11 years old & 19 & 54.28 \\
\hline 12 to 18 years old & 16 & 45.72 \\
\hline \multicolumn{3}{|l|}{ Race } \\
\hline Brown & 05 & 14.28 \\
\hline White & 02 & 5.71 \\
\hline Yellow & 01 & 2.85 \\
\hline Not informed & 27 & 77.16 \\
\hline \multicolumn{3}{|l|}{ Occupation } \\
\hline Student & 21 & 60.00 \\
\hline Farmer & 01 & 2.85 \\
\hline Not informed & 13 & 37.15 \\
\hline \multicolumn{3}{|l|}{ Education level } \\
\hline Incomplete elementary school & 03 & 8.57 \\
\hline Complete elementary education & 02 & 5.71 \\
\hline Incomplete high school & 01 & 2.85 \\
\hline Complete high school & 01 & 2.85 \\
\hline Not informed & 28 & 80.02 \\
\hline \multicolumn{3}{|l|}{ Local de residence } \\
\hline $\mathrm{RN}$ & 25 & 71.42 \\
\hline Other states & 10 & 28.58 \\
\hline Total & 35 & 100.00 \\
\hline
\end{tabular}


The distribution of patients according to gender did not present a statistically significant difference, with $51.42 \%$ of the male patients. A 17 year follow-up study in institutions in the Brazilian states of Paraná and São Paulo, with patients younger than 19 years old submitted to HSCT had a greater number of males, of whom 74 were females and 137 were male (MORANDO et al., 2010).

Regarding their race, only $22.84 \%$ of the medical records presented this information. Underreporting is a situation commonly found in health information systems. It is important that all necessary patient information is recorded not only for research purposes but for the patient, also for consultation by medical, administrative and legal professionals. Therefore, in this case, it was not possible to compare these data with other studies, although underreporting of the breed has been commonly found in several studies (SOUZA et al., 2017).

The main diagnoses were Acute Lymphoblastic Leukemia (ALL) with $34.3 \%$ of cases and Acute Myeloid Leukemia (AML) with $25.71 \%$, respectively. Gastrointestinal toxicities occurred in $97.1 \%$ of the cases and $100 \%$ of the subjects received antineoplastic/chemotherapeutic and antiemetic treatment.

According to the types of HSCT performed, $57.14 \%$ were submitted to allogeneic transplantation, the most used source of HPC was Peripheral blood (PB) (54.29\%), only $8.56 \%$ were retransplanted and $5.71 \%$ developed GVHD, one affected by acute GVHD and another affected by a chronic form. Sepsis developed $60 \%$ of deaths (Table 2).

Table 2. Clinical characteristics of children and adolescents submitted to HSCT in the state of Rio Grande do Norte between 2008 and 2015. Natal/RN, $2017(\mathrm{n}=35)$.

\begin{tabular}{|c|c|c|}
\hline Variables & $\mathbf{n}$ & $\%$ \\
\hline \multicolumn{3}{|l|}{ Main Diagnosis } \\
\hline Acute Lymphoblastic Leukemia (ALL) & 12 & 34.30 \\
\hline Acute Myeloid Leukemia (AML) & 09 & 25.71 \\
\hline Anemia Aplastic (AA) & 05 & 14.30 \\
\hline Hodgkin's Disease (HD) & 02 & 5.72 \\
\hline Sickle Cell Anemia (SCA) & 02 & 5.72 \\
\hline Others & 05 & 14.25 \\
\hline \multicolumn{3}{|l|}{ Main toxicities* } \\
\hline Gastrointestinal & 34 & 97.10 \\
\hline Cardiovascular & 22 & 62.85 \\
\hline Respiratory & 22 & 62.85 \\
\hline Hematologic & 21 & 60.00 \\
\hline \multicolumn{3}{|l|}{ Main treatments used" } \\
\hline Antineoplastic Agents/Chemotherapeutics & 35 & 100.00 \\
\hline Antiemetic & 35 & 100.00 \\
\hline Antibiotic & 34 & 97.14 \\
\hline Peptic antiulcer & 34 & 97.14 \\
\hline \multicolumn{3}{|l|}{ Type of TCTH performed } \\
\hline Allogenic & 32 & 91.42 \\
\hline Autologous & 03 & 8.58 \\
\hline \multicolumn{3}{|l|}{ Type of HPC used } \\
\hline Peripheral blood & 19 & 54.29 \\
\hline Bone marrow & 11 & 31.42 \\
\hline The umbilical cord & 03 & 8.58 \\
\hline Not informed & 02 & 5.71 \\
\hline \multicolumn{3}{|l|}{ Donor for allogeneic HSCT } \\
\hline Not related & 20 & 57.14 \\
\hline Related & 12 & 34.30 \\
\hline Not informed & 03 & 8.56 \\
\hline \multicolumn{3}{|l|}{ GVHD } \\
\hline Yes & 02 & 5.71 \\
\hline No & 32 & 94.29 \\
\hline
\end{tabular}




\begin{tabular}{lll}
\hline Sepsis & 03 & 60.00 \\
Hypovolemic shock & 01 & 20.00 \\
Septic shock & 01 & 20.00 \\
\hline Total & $\mathbf{3 5}$ & $\mathbf{1 0 0 . 0 0}$ \\
\hline
\end{tabular}

${ }^{*}$ Multiple choice.

The diagnosis of the base disease for most frequent HSCT was ALL (34.3\%), followed by AML $(25.71 \%)$. A study with children younger than 3 years old demonstrated similar results when the most common diagnoses were ALL (66.7\%) and AML (26.7\%) (LEVY et al., 2012). Another study carried out with children and adolescents with leukemia showed a higher prevalence for ALL (199) on AML (89) (MORANDO et al., 2010). ALL is the most common type of cancer found in children (INSTITUNO NACIONAL DO CÂNCER JOSÉ ALENCAR GOMES DA SILVA, 2017).

HSCT shows a strong focus on the clinical cure process, with the use of intensive therapy with high risk of treatment-related toxicity and unpredictable complications. The main toxicities found in the subjects of this study were gastrointestinal (97.1\%), followed by cardiovascular $(62.85 \%)$, respiratory $(62.85 \%)$ and hematologic $(60 \%)$ (SANTOS, 2015). The toxicities have a great relationship with the complications related to the conditioning period (FIGUEIREDO; KERBAUY; LOURENÇO, 2011), as well as the gastrointestinal toxicities are risk factors for the infection, so it is necessary to invest in techniques for its prevention (SRINIVASAN et al., 2014).

To perform a HSCT, the patient undergoes the conditioning process, which aims to generate immunosuppression to prevent the donor cells from being rejected by the recipient. This process occurs through irradiation and/or chemotherapy, so all patients in this study underwent antineoplastic/chemotherapeutic treatment (GRATWOHL; CARRERAS, 2013; JURIC et al., 2016).

High doses of radiotherapy and/or chemotherapy used in conditioning can affect all of the patient's organs and lead to side effects. The development of complications may be related to predisposition, immunosuppressive therapies and toxicities related to pre-transplant therapies and presence of other factors during the conditioning regimen (HABIBI et al., 2016).

The use of antibiotics may be indicated as prophylactic therapy, because in the months after transplantation, the occurrence of infections due to immunosuppression caused by the conditioning and the treatment used to avoid GVHD is common. Therefore, a wide range of prophylactic drugs is used (FIGUEIREDO; KERBAUY; LOURENÇO, 2011). With the establishment of antiviral and antifungal prophylaxis after the 2000s, there was a significant reduction in the incidence and characteristics of infections in these patients (SRINIVASAN et al., 2014).

Infection complications are among the main causes of transplant-related morbidity and mortality (MAJHAIL et al., 2012; YEŞILIPEK, 2014). In this study, the use of antibiotics occurred in $97.14 \%$ of the subjects studied, which demonstrates the concern with the cases of infection of patients transplanted with HTCs.

Antiemetics are used in all patients as a consequence of the administration of antineoplastic/chemotherapeutic agents, as the case with the studied individuals, since the main side effects of alkylating drugs are nausea and emesis (SANTOS, 2015). Gastrointestinal complications are responsible for a significant part of the morbidity and mortality due to dehydration, malnutrition and hydroelectrolytic imbalance (TUNCER et al., 2017) and, they can be fatal and require special attention when they occur in children and adolescents.

The anti-neoplastic treatment may also cause hematological toxicity, reducing the cell lines of the blood and leading the patients to myelosuppression, with leukopenia, thrombocytopenic/thrombocytopenic progression, anemia or medullary depression (POZER et al., 2012). Hematopoietic tissue is more vulnerable to cytotoxic drugs, since chemotherapeutics are toxic to rapidly proliferating tissues, characterized by high mitotic index and a short cell cycle (SANTOS, 2015).

Cardiovascular complications associated with cardiotoxicity are adverse events that can occur acutely or chronically, with significant morbidity and mortality for children and young adults, and they may also lead to heart failure, arterial hypertension, metabolic syndromes, thromboembolism, pericarditis, arrhythmias or ischemia (ROTZ et al., 2017).

Pulmonary complications affect about $40 \%$ to $60 \%$ of $\mathrm{CPH}$ transplants and are considered important causes of morbidity and mortality. According to some studies, pulmonary toxicity is responsible for $50 \%$ of deaths IN transplanted 
patients, and patients with pulmonary complications are more likely to die than those who do not present these complications (BRODOEFEL et al., 2013; PEÑA et al., 2014).

Although the first allogeneic HSCT was performed in 1957 by the Nobel laureate E. Donnall Thomas (HENIG; ZUCKERMAN, 2014), studies have shown a reduction in cases of autologous transplants only after the 2000s. A study with 65 patients undergoing autologous HSCT found $92 \%$ of autologous transplants from 1990-1999 compared to $8 \%$ performed between 2000 and 2009 (SRINIVASAN et al., 2014).

In this study, autologous transplantation was performed in only three patients. The other 32 underwent allogeneic transplantation. A study carried out in the United States of America with medical records of patients who died after the procedure found similar results, when $69 \%$ of the transplants were allogenic, $18 \%$ autogenic and $13 \%$ through Umbilical Cord and Placental Blood (UCPB) (ULLRICH et al., 2016). The results of autologous transplants are superior due to the complications most common to allogeneic transplants. However, allogeneic transplants have a long-term gain because they present a lower frequency of relapse, which may justify the choice of the source of cells for transplantation (FIGUEIREDO; KERBAUY; LOURENÇO, 2011). Another reason for a predominance of allogeneic transplants is due to the fact that some diseases related to immune deficiencies have allogeneic transplantation as the only therapeutic option for cure (YEŞILIPEK, 2014).

PB was the source of progenitor cells predominantly employed in HSCT $(54.29 \%)$ of the patients of this study, differently from the literature, where the bone marrow is highlighted as a source of material for the graft (MORANDO et al., 2010). In this study, BM was the second largest source $(31.42 \%)$, while umbilical cord blood (8.58\%) was the least used source, although it is sources with satisfactory results, many difficulties still exist for its wide use.

From the 2000s, there was a preference for other cellular sources other than the bone marrow (SRINIVASAN et al., 2014). Although survival rates are similar between the use of $\mathrm{PB}$ and $\mathrm{BM}$ cells, graft success is achieved in the case of PB more rapidly than bone marrow transplantation (MEISEL; KLINGEBERL, DILOO, 2013).

The prevalence of chronic GVHD in patients undergoing HSCT is about $40 \%$ to $60 \%$ and is the main cause of late mortality, mainly associated with infections (FIGUEIREDO; KERBAUY; LOURENÇO, 2011). Although it has decreased with new methods of conditioning and with and a lower risk in pediatric patients compared to adults, this frequency has increased especially by the use of allogeneic and unrelated transplants (YEŞILIPEK, 2014).

In this case, the patients in this study had $5.81 \%$ rate of GVHD, even when related to a number of 19 grafts from SP, which presents a higher incidence of this complication (SHAW et al., 2009). A study conducted in this same service with pediatric and adult patients presented a small rate of occurrence of GVHD (4.04\%) and a high HSCT rate of PB cells (77.94\%; p<0.400) (AZEVEDO et al., 2018) that confirms there was no relation between the occurrence of GVHD and the cellular source from PB. Although the two cases of GVHD caught the attention, the number of manifestations occurred within the expected incidence. The expected frequency of acute GVHD was reported between 30 and $50 \%$ of the cases of children undergoing HSCT (YEŞILIPEK, 2014).

Of the five patients who died, all were adolescents, and $80 \%$ were male. Only one of the deaths occurred within the first seven months of treatment. Among the five deaths, three had diagnosis of ALL, one of AML and another of Aplastic Anemia (Table 3).

Table 3. Characterization of the deaths of children and adolescents submitted to HSCT in the state of Rio Grande do Norte between 2008 and 2015. Natal/RN, $2017(n=5)$.

\begin{tabular}{lcc}
\hline Variables & n & \% \\
\hline Gender & & \\
$\quad$ Male & 04 & 80.00 \\
$\quad$ Female & 01 & 20.00 \\
Age group & & \\
$\quad$ 12 to 18 years old & 05 & 100.00 \\
$\quad$ Follow up time & & \\
$\quad$ Up to 7 months & 01 & 20.00 \\
$\quad$ More than 7 months & 04 & 80.00 \\
\hline
\end{tabular}




\begin{tabular}{lll} 
Main Diagnosis & & \\
Acute Lymphoblastic Leukemia & 03 & 60.00 \\
Acute Myeloid Leukemia & 01 & 20.00 \\
Anemia, Aplastic & 01 & 20.00 \\
\hline Total & $\mathbf{0 5}$ & $\mathbf{1 0 0 . 0 0}$ \\
\hline
\end{tabular}

This study corroborates most of the studies, when infections are an important cause of mortality in children and adolescents treated with allogeneic HTCs, with a high incidence of infections in this group of patients (ZAUCHA-PRAZMO et al., 2017; PASQUINI; ZHU, 2014). In a contradictory way, a study carried out in the USA presented a rate of $59.18 \%$ of the deaths related to treatment toxicity and the others related to recurrence of the disease. An important finding in this study is that although a $91.42 \%$ rate of allogeneic transplants, which is related to a greater number of infections, the mortality rate was $14.28 \%$, which may be considered low (STYCZYNSKI et al., 2016).

Progress in the treatment of childhood and adolescent cancer in the last four decades has been extremely significant. Changes in treatment and prophylaxis have helped in this progress (SRINIVASAN et al., 2014). With this advancement, about $80 \%$ of children and adolescents affected by cancer can be cured if diagnosed early and treated in specialized centers (BRASIL, 2008), although childhood survivors of HSCT have a risk for dysfunction in all systems, as well as secondary tumors (LEVY et al., 2012).

One limitation of this study is that it deals with research performed with secondary data, from medical records that could be incomplete. However, in cases where it was not possible to collect the necessary information directly related to the object being studied, the medical records were excluded from the analyzed sample as a way to control this information bias. Also, the unicentric approach and sample size considered small for epidemiological studies are limiting factors for the external validity of the study.

This study constitutes an important starting point for the clinical and epidemiological analysis of children and adolescents submitted to HSCT, which still deals with a procedure that requires expanded studies in Brazil and in the world, mainly because it is the highlighted population. There are few studies that show the epidemiological data of children and adolescents transplanted in Brazil, with specific surveys, without a national survey to establish the profile of this national patients. Besides to promoting a discussion on the subject treated, the research incites the opportunity to know the profiles of patients assisted in the services of HSCT that can help in the understanding and the choice of better therapeutic options.

The profile of the clinical variables of the children and adolescents in this study showed that ALL was the most prevalent diagnosis, gastrointestinal, cardiac, respiratory and hematological were the most frequent toxicities, allogeneic peripheral blood was the most performed HSCT and sepsis was the major cause of mortality. These data are similar to data found in North America, Europe and Asia, except for the use of peripheral blood HPC when research in Europe, Asia, and the United States already demonstrated a significant number of cord blood and placental procedures.

Additional studies with a larger number of patients and in other reference services in Brazil are necessary to link the aspects described in the results and show the Brazilian reality to contribute to the advancement in health research. Although there are few distinctions, this study allowed concluding that the epidemiological characteristics of the patients of a Brazilian service do not differ from those performed with populations of international studies.

\section{CONFLICTS OF INTEREST}

The authors declare that there is no conflict of interest regarding the publication of this article. The submitting authors are responsible for coauthors declaring their interests.

\section{ACKNOWLEDGMENT}

Coordenação de Aperfeiçoamento de Pessoal de Nível Superior (CAPES - Master and Doctorate scholarship).

RESUMO: O Transplante de Células-Tronco Hematopoéticas (TCTH) é utilizado em crianças como um tratamento definitivo para várias doenças oncológicas, imunodeficiências, hemoglobinopatias, malignidades que envolvem o sistema hematológico, distúrbios de metabolismo congênito, entre outros. Caracterizar o perfil clínico e epidemiológico de crianças e adolescentes submetidos ao TCTH em um serviço de referência do 
estado do Rio Grande do Norte. Trata de um estudo epidemiológico de abordagem quantitativa, do tipo coorte retrospectiva, observacional, descritivo e analítico onde foram abordados os prontuários de crianças e adolescentes submetidos ao TCTH em um serviço hospitalar de referência para esse tipo de transplante no estado do Rio Grande do Norte (RN). A amostra final foi composta por 35 prontuários de pacientes com idade entre dois e 18 anos que realizaram o TCTH no período de fevereiro de 2008 a dezembro de 2015 e que apresentavam os dados necessários ao estudo. Do total de prontuários analisados houve discreta maioria de pacientes do sexo masculino (51,42\%). Destes, $60,00 \%$ eram estudantes e $71,42 \%$ residiam no estado do RN. De acordo com as características clínicas, 34,3\% apresentaram como diagnóstico principal a Leucemia Linfoblástica Aguda e 25,71\% a Leucemia Mieloide Aguda. As toxicidades gastrointestinais foram as que mais ocorreram $(97,1 \%)$ e todos receberam tratamento com antineoplásicos/quimioterápicos e antieméticos. $\mathrm{O}$ TCTH alogênico foi o mais frequentemente realizado $(57,14 \%)$ e a fonte de $\mathrm{CPH}$ mais utilizada foi o sangue periférico $(54,29 \%)$ e $5,71 \%$ desenvolveram a Doença do Enxerto Contra Hospedeiro (DECH), dos quais um foi acometido por DECH aguda e outro pela forma crônica. A causa de morte com maior frequência foi a sepse (60\%). O perfil das variáveis clínicas apresentadas pelas crianças e adolescents desta pesquisa mostram que o diagnóstico mais prevalente foi o de LLA, as toxicidades que mais ocorreram foram as gastrointestinais, cardíacas, respiratórias e hematológicas, o TCTH mais realizado foi o alogênico de sangue periférico e a maior causa de mortalidade foi a sepse. Tais dados se assemelham aos estudos realizados na América do Norte, Europa e Ásia.

PALAVRAS-CHAVE: Transplante de Células-Tronco Hematopoéticas. Transplante de Medula Óssea. Criança. Adolescente. Epidemiologia.

\section{REFERÊNCIAS}

AZEVEDO, I. C.; CASSIANO, A. N.; CARVALHO, J. B. L.; FERREIRA JÚNIOR, M. A. Nursing care for hematopoietic stem cell transplant recipients and their families. Rev Rene. v. 18, n. 4, p. 559-66, 2017 a. https://doi.org/10.15253/2175-6783.2017000400019

AZEVEDO, I. C.; FERREIRA JÚNIOR, M. A.; SILVA, R. C. L.; OLIVEIRA. A. A.; AQUINO, L. A. P.; CÂMARA, P. F. M. et al. Therapies that favor an increase in overall survival of patients submitted to hematopoietic stem cell transplantation: systematic review. Wulfenia Journal. v. 24, n. 9, 2017 b.

AZEVEDO, I. C.; FERREIRA JÚNIOR, M. A.; AQUINO, L. A. P.; OLIVEIRA, A. A.; CRUZ, G. K. P.; CARDOSO, A. I. Q. et al. Epidemiologic Profile of Patients Transplanted With Hematopoietic Stem Cells in a Reference Service in the State of Rio Grande do Norte, Brazil. Transplantation Proceedings. v. 50, n. 3, p. 819-23, 2018. https://doi.org/10.1016/j.transproceed.2018.02.015

BOUCHER, A. A.; MILLER, W.; SHANLEY, R.; ZIEGLER, R.; LUND, T.; RAYMOND, G.; ORCHARD, P. J. Long-term outcomes after allogeneic hematopoietic stem cell transplantation for metachromatic leukodystrophy: the largest single-institution cohort report. Orphanet Journal of Rare Diseases. v. 10, n. 94, 2015. https://doi.org/10.1186/s13023-015-0313-y

BRASIL. Presidência da República. Subchefia para Assuntos Jurídicos. Casa Civil. Lei No 8.069, de 13 de julho de 1990. Dispõe sobre o Estatuto da Criança e do Adolescente e dá outras providências. Disponível em: <http://www.planalto.gov.br/ccivil_03/leis/L8069.htm>. Acesso em: 17 nov. 2017.

BRASIL. Instituto Nacional de Câncer. Ações de enfermagem para o controle do câncer: uma proposta de integração ensino-serviço. 3. ed. atual. amp. Rio de Janeiro: INCA, 2008.

BRODOEFEL, $\mathrm{H}$. et al. Therapy-related noninfectious complications in patients with hematologic malignancies: high-resolution computed tomography findings. J Thorac Imaging. v. 28, n. 1, p. 5-11, 2013. https://doi.org/10.1097/RTI.0b013e31822031f0 
DANBY, R. D.; PROTHEROE, R.; ROBERTS, D. J. Haematopoietic stem cell transplantation. In: MURPHY, M. F., ROBERTS, D. J., YAZER, M. H. Pratical transfusion medicine. 5. ed. Wiley-Blackwell, 2017. p. 540562. https://doi.org/10.1002/9781119129431.ch41

DUFORT, G.; CASTILLO, G.; PISANO, S.; CASTIGLIONI, M.; CAROLINA, P.; ANDREA, I. et al. Haploidentical hematopoietic stem cell transplantation in children with high-risk hematologic malignancies: outcomes with two different strategies for GvHD prevention. Ex vivo T-cell depletion and post-transplant cyclophosphamide: 10 years of experience at a single center. Bone Marrow Transplant. v. 51, p. 1354-60, 2016. https://doi.org/10.1038/bmt.2016.161

FIGUEIREDO, M. S.; KERBAUY, J.; LOURENÇO, D. M. Hematologia: Guia de medicina ambulatorial da UNIFESP-EPM. Barueri: Manole, 2011. Cap. 14.

GLUCKMAN, E. A brief history of HSCT. In: APPERLEY, L. et al. (Eds.). Handbook on haemopoietic stem cell transplantation. London: ESH/EBMT, 2012. Cap. 1. p. 21-27. Disponível em:

<https://ebmtonline.forumservice.net/media/01/main.html>. Acesso em: 19 nov. 2017.

GRATWOHL, A.; CARRERAS, E. Principles of conditioning. In: APPERLEY, L. et al. (Eds.). Handbook on haematopoietic stem cell transplantation. 6. ed. London: ESH/EBMT, 2013. Cap. 8. p. 122-37. Disponível em: <https://ebmtonline.forumservice.net/media/08/main.html>. Acesso em: 19 nov. 2017.

HABIBI, M.; NAMIMOGHADAM, A.; KOROUNI, R.; FASHIRI, P.; BORZOUEISILEH, S.;

ELAHIMANESH, F. et al. Radiation-induced nausea and vomiting is ABO blood group as important as radiation and patient-related factors? An observational study. Medicine (Baltimore). v. 95, n. 31, 2016. https://doi.org/10.1097/MD.0000000000004334

HENIG, I.; ZUCKERMAN, T. Hematopoietic stem cell transplantation - 50 years of evolution and future perspectives. Rambam Maimonides Med J. v. 5, n. 4, p. 1-15, 2014. https://doi.org/10.5041/RMMJ.10162

INSTITUTO NACIONAL DO CÂNCER JOSÉ ALENCAR GOMES DA SILVA. Coordenação de Prevenção e Vigilância. Estimativa 2018: incidência de câncer no Brasil. Rio de Janeiro: INCA, 2017. 128 p.

JURIC, M. K.; GHIMIRE, S.; OGONEK, O.; WEISSINGER, E. M.; HOLLER, E.; VAN ROOD, J. J.; OUDSHOORN, M.; DICKINSON, A.; GREINIX, H. T. Milestones of hematopoietic stem cell transplantation - From First Human Studies to Current Developments. Journal Frontiers in Immunology. v. 7, n. 470, 2016. https://doi.org/10.3389/fimmu.2016.00470

KLUSMANN, J-A.; REINHARDT, D.; ZIMMERMANN, M.; KREMENS, B.; VORMOOR, J.; DWORZAK, M.; CREUTZIG, U.; KLINGEBIEL, T. The role of matched sibling donor allogeneic stem cell transplantation in pediatric high-risk acute myeloid leukemia: results from the AML-BFM 98 study. Haematologica. v. 97, n. 1, p. 21-9, 2012. https://doi.org/10.3324/haematol.2011.051714

LEVY, J. M.; TELLO T.; GILLER, R.; WILKENING, G.; QUINONES, R.; KEATING, A.; LIU, A. K. Late effects of total body irradiation and hematopoietic stem cell transplant in children under three years of age.

Pediatric Blood and Cancer. v. 60, n. 4, p. 700-4, 2012. https://doi.org/10.1002/pbc.24252

MAJHAIL, N. S.; RIZZO, J. D.; LEE, S. J.; ALJURF, M.; ATSUTA, Y.; BONFIM, C. et al. Recommended Screening and Preventive Practices for Long-Term Survivors after Hematopoietic Cell Transplantation. Bone Marrow Transplant. v. 47, n. 3, p. 337-41. 2012. https://doi.org/10.1016/j.bbmt.2011.12.519

MEISEL, R.; KLINGEBIEL, T.; DILLOO, D. Peripheral blood stem cells versus bone marrow in pediatric unrelated donor stem cell transplantation. Blood. v. 121, n. 5, p. 863-5, 2013. https://doi.org/10.1182/blood2012-12-469668 
MORANDO, J.; MAUAD, M. A.; FORTIER, S. C.; PIAZERA, F. Z.; SOUZA, M. P.; OLIVEIRA, C. et al. Transplante de células-tronco hematopoéticas em crianças e adolescentes com leucemia aguda: experiência de duas instituições Brasileiras. Rev Bras Hematol Hemoter. v. 32, n. 5, p. 350-7, 2010.

https://doi.org/10.1590/S1516-84842010000500006

NASH, R. A.; GADI, V. K. Hematopoetic stem cell transplantation. In: MYER, M. W. Wintrobe's Clinical Hematology. 13. ed. Philadephia: Wolters Kluwer/Lippincott Williams \& Wilkins Health, 2011. Cap. 24, p. 722-48.

NORKIN, M.; WINGARD. J. R. Recent advances in hematopoietic stem cell transplantation. F1000 Res. v. 6, p. 870-6, 2017. https://doi.org/10.12688/f1000research.11233.1

PASQUINI, M. C.; ZHU, X. Current use and outcome of hematopoietic stem cell transplantation. CIBMTR summary slides, 2014. Disponível em: <http://www.cibmtr.org.>. Acesso em: 23 nov. 2017.

PEÑA, E.; SOUZA, C. A.; ESCUISSATO, D. L.; GOMES, M. M.; ALLAN, D.; TAY, J.; DENNIE, C. J. Noninfectious pulmonary complications after hematopoietic stem cell transplantation: practical approach to imaging diagnosis. RadioGraphics. v. 4, n. 3, 2014. https://doi.org/10.1148/rg.343135080

POZER, M. Z.; SILVA, T. A.; REGINO, P. A.; FERNANDES JÚNIOR, P. C.; SILVA, S. R. Sinais e sintomas de mielodepressão por quimioterapia no domicílio, entre portadoras de câncer ginecológico. Cienc Cuid Saude. v. 11, n. 2, p. 336-42, 2012. https://doi.org/10.4025/cienccuidsaude.v11i2.14984

ROTZ, S. J.; RYAN, T. D.; HLAVATY, J.; GEORGE, S. A.; BIETAR, J. E.; DANDOY, C. E. Cardiotoxicity and cardiomyopathy in children and young adult survivors of hematopoietic stem cell transplant. Pediatr Blood Cancer. v. 64, n. 11, 2017. https://doi.org/10.1002/pbc.26600

SANTOS, K. B. Efetividade e toxicidade de protocolo de condicionamento em transplante autólogo de célula-tronco hematopoética para pacientes com linfoma. 2015. Tese (doutorado). Programa de Pósgraduação em Saúde, Faculdade de Medicina, Universidade Federal de Juiz de Fora, Juiz de Fora (MG), 2015.

SHAW, B. E.; APPERLEY, J.; RUSSELL, N. H.; CRADDOCK, C. F.; LIAKOPOULOU, E.; POTTER, M. N. et al. A comparison of stem cell source in adult and paediatric recipients of T-cell depleted myeloablative transplants for standard risk leukaemia: No Difference in Mortality Using BM or PBSC. Blood. v. 114, p. 1205, 2009.

SOUZA, A. A.; SERAFIM, A, I. S.; SOUSA, F. A. D.; SOUZA, G. K. T.; SILVA, I. S. R.; GOMES, R. K. G. Segurança do paciente a nível hospitalar: importância da qualidade dos registros em prontuários. Mostra Interdisciplinar do Curso de Enfermagem. v. 2, n. 2, 2017. Disponível em: <http://publicacoesacademicas.fcrs.edu.br/index.php/mice/article/view/1164/937>. Acesso em: 04 dez. 2017.

SRINIVASAN, A.; SRINIVASAN, S.; SUNTHANKAR, S.; SUNKARA, A.; KANG, G.; STOKES, D. C.; LEUNG, D. Pre-hematopoietic stem cell transplant lung function and pulmonary complications in children. Ann Am Thorac Soc. v. 11, n. 10, p. 1576-85, 2014. https://doi.org/10.1513/AnnalsATS.201407-308OC

STYCZYNSKI, J.; CZYZEWSKI, K.; WYSOCKI, M.; GRYNIEWICZ-KWIATKOWSKA, O.; KOLODZIEJCZYK-GIETKA, A.; SALAMONOWICZ, M. et al. Increased risk of infections and infectionrelated mortality in children undergoing haematopoietic stem cell transplantation compared to conventional anticancer therapy: a multicentre nationwide study. Clin Microbiol Infect. v. 22, n. 2, 2016. https://doi.org/10.1016/j.cmi.2015.10.017

TUNCER, H. H.; RANA, N.; MILANI, C.; DARKO, A.; AL-HOMSI, S. A. Gastrointestinal and hepatic complications of hematopoietic stem cell transplantation. World J Gastroenterol. v. 18, n. 16, p. 1851-60, 2012. https://doi.org/10.3748/wjg.v18.i16.1851 
ULLRICH, C. K.; LEHMANN, L.; LONDON, W. B.; GUO, D.; SRIDHARAN, M.; KOCH, R.; WOLFE, J. Life Care Patterns Associated with Pediatric Palliative Care among Children Who Underwent Hematopoietic Stem Cell Transplant. Biol Blood Marrow Transplant. v. 22, n. 6, p. 1049-55, 2016. https://doi.org/10.1016/j.bbmt.2016.02.012

YEŞILIPEK, M. A. Hematopoetic stem cell transplantation in children. Turk Pediatri Ars. v. 49, n. 2, p. 91-8, 2014. https://doi.org/10.5152/tpa.2014.2010

ZAUCHA-PRAZMO, A.; KOWALCZYK, J. R.; DRABKO, K.; CZYŻEWSKI, K.; GOŹDZIK, J.; ZAJĄCSPYCHAŁA, O. et al. Incidence of infectious complications in children with acute lymphoblastic leukemia treated with hematopoietic stem cell transplantation. Transplant Proc. v. 49, n. 9, p. 2183-7. 2017.

https://doi.org/10.1016/j.transproceed.2017.09.027 